\title{
OPTIMIZATION OF THE LOCATION OF A CAR CRANE FOR PERFORMING THE INSTALLATION OF THE STRUCTURE
}

\section{R. MARCINKOWSKI ${ }^{1}$, M. BANACH ${ }^{2}$}

\begin{abstract}
The paper presented the model of a problem of choosing the location of a car crane for the installation of prefabricated elements in a given assembly situation with the solution proposal. The issue relates to the situation, in which the dimensions of the shielding structure (assembled) are specified, sizes and weights of the prefabricated elements with their location on the structure. The solution seeks the best location of a crane from the point of view of the parameters of the crane, scope and height of the lift.
\end{abstract}

Keywords: organisation of the assembly, installation of prefabricates, a car crane

\section{ESSENTIAL TECHNICAL PARAMETERS OF A CAR CRANE FOR PERFORMING THE INSTALLATION}

The selection of assembly devices for the implementation of installation works on the given construction site should be preceded by establishing of the necessary technical parameters, which should characterise these devices in the worst possible situations of their work. These parameters include the necessary: capacity $-Q_{\min }$, outreach $-L_{\min }$ and height of lifting $-H_{\min }$. We determine them by considering several situational characteristics in the planned assembly - situations, which generate the most unfavourable installation situations.

\footnotetext{
${ }^{1}$ DSc., Eng., (associate prof. PW) Warsaw University of Technology, Faculty of Civil Engineering, Mechanics and Petrochemistry, ul. Łukasiewicza 17,09-400 Płock, email: marcinkowski@pw.plock.pl

${ }^{2}$ MSc., Eng., Warsaw University of Technology, Faculty of Civil Engineering, Mechanics and Petrochemistry, ul. Łukasiewicza 17, 09-400 Płock, e-mail: mbanach@pw.plock.pl
} 
Identifying these situations is not easy, especially for car cranes. Because one must specify these parameters in the mutual relationship, in order to verify whether the device planned for the assembly will ensure their fulfilment. Mobile cranes have the appropriate characteristics, defined by parameters $\{Q, L, H\}$. They can be used when their characteristics are more than $\left\{Q_{\min }, L_{\min }, H_{\min }\right\}$. Books on the technology of construction works, e.g. [4, 5] identify different assembly situations and provide many dependencies for determining the necessary parameters of the assembly machine. The generalised assembly situation is presented in figure 1. This figure identifies the parameters for the mobile crane used to assemble the elements on a shuttering structure (assembled).

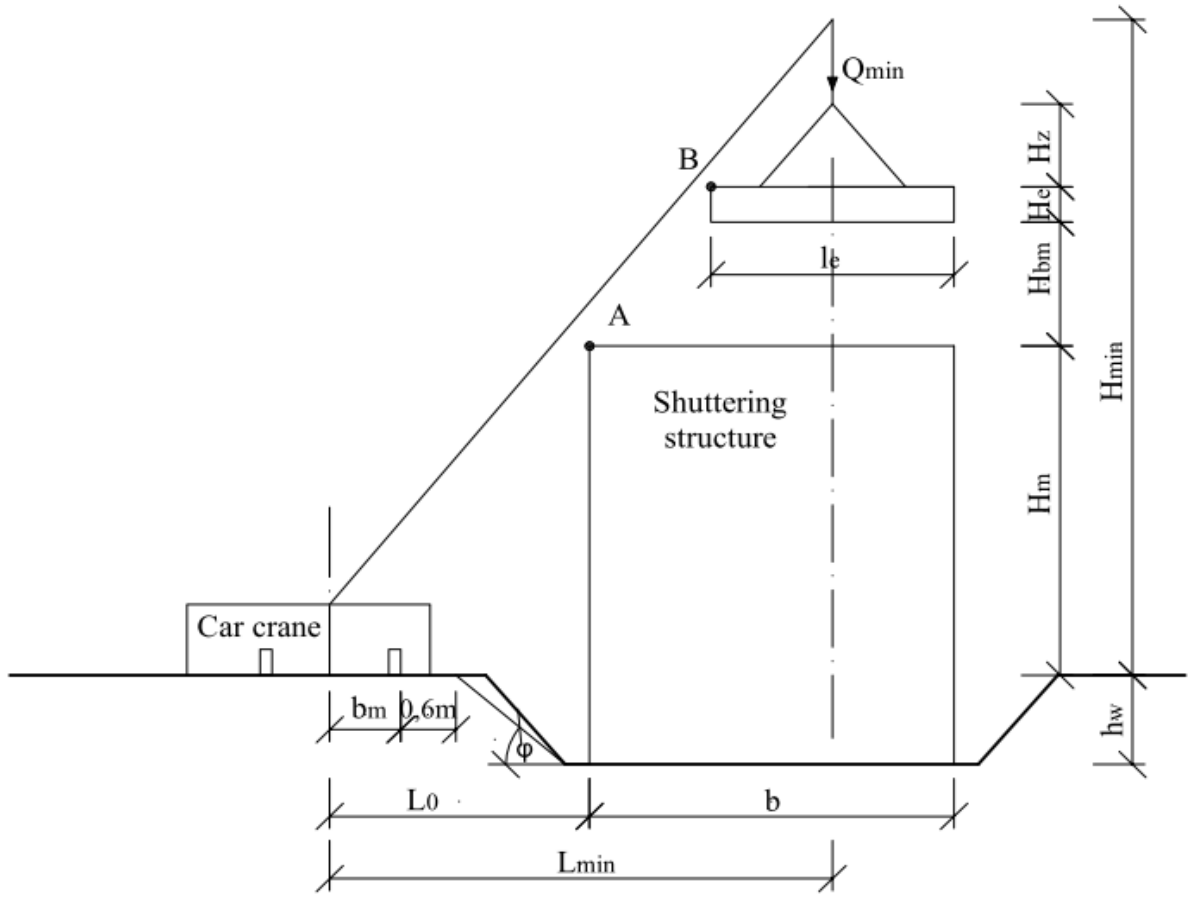

Fig. 1. Diagram of an assembly situation of a mobile crane with markings of characteristic data.

The necessary capacity $\left(Q_{\mathrm{min}}\right)$ of the assembly machine, results from the mass of the lifted element, suspension mass and the possible securing structure. We determine it from the formula:

$$
Q_{\min } \geq\left[\left(Q_{e}+Q_{z}+Q_{d o d}\right) / n\right] \cdot S_{o} \cdot \gamma
$$


where:

$Q_{e}$ - the weight of the element (prefabricate), $Q_{z}$ - weight of suspension, $Q_{d o d}$ - weight of the potential structure securing the element during the installation of the element, $\mathrm{n}$ - amount of used installation machines, $S_{o}-$ uneven load factor of the applied assembly machines, $\gamma$ - coefficient compensating other relations not included in calculations

The necessary range (radius) $L_{\min }$ results from the analysis of the assembly situation - the shape of the building on the plan. Considering the generalised situation as in (Fig. 1) the necessary radius can be determined from the condition:

$$
L_{\min } \geq b_{m}+0,5+\frac{h_{w}}{\operatorname{tg} \varphi}+b-\frac{b_{e}}{2}
$$

where:

$b_{\mathrm{m}}$ - the distance from the extreme point of the support of the crane foot to its rotation axis), $b_{\mathrm{e}}-$ the width of the mounted element, $h_{\mathrm{w}}$ - the depth of the excavation, $\varphi$ - the angle of the land faction at the loaded level.

If the excavation is not present in the considered situation, the distance of the crane from the shuttering structure $L_{0}$ is determined based on the analysis of the spatial situation andoptimizing the location of a crane in relation to the shuttering structure - what will be the subject of the further part of the work.

To be able to assemble the element on its destined location three conditions must be met:

- due to the height of the assembly:

$$
H_{\min } \geq H_{m}+H_{b m}+H_{e}+H_{z}
$$

- due to the size of the shuttering structure (in fig. 1. - the safe distance of the reach from point A):

$$
\frac{H_{\min }}{L_{\min }} \geq \frac{H_{m}}{L_{0}} \Rightarrow H_{\min } \geq L_{\min } \cdot \frac{H_{m}}{L_{0}}
$$

- due to the dimensions of the mounted element (in fig. 1. - the safe distance of the reach from point B):

$$
\frac{H_{\min }}{L_{\min }} \geq \frac{H_{m}+H_{b m}+H_{e}}{L_{\min }-\frac{b_{e}}{2}} \Rightarrow H_{\min } \geq \frac{L_{\min } \cdot\left(H_{m}+H_{b m}+H_{e}\right)}{L_{\min }-\frac{b_{e}}{2}}
$$

It is easy to notice that the third condition is irrelevant for mounting vertical elements (e.g. columns). The above relations results show that the location of a crane in relation to the assembled 
structure affects the necessary height of lifting, which here is understood as necessary under the given conditions of height of the lifting of the assembly machine hook over the level of the position of this machine. Location of the machine with respect to the mounted structure, location of administration of prefabricates and their sizes and weights affects the needed parameters $\left\{Q_{\text {min }}\right.$, $\left.L_{\min }, H_{\min }\right\}$, or the other way round, from the assembly characteristics of a crane result possibilities to administer prefabricates on the mounted structure.

\section{PROBLEM OF THE LOCATION OF THE CAR CRANE FOR THE ASSEMBLY OF PREFABRICATES}

The location of the car crane should enable the performance of the assembly of the specified set of prefabricates on the built object. Prefabricates frequently have different sizes and weights and different installation locations.
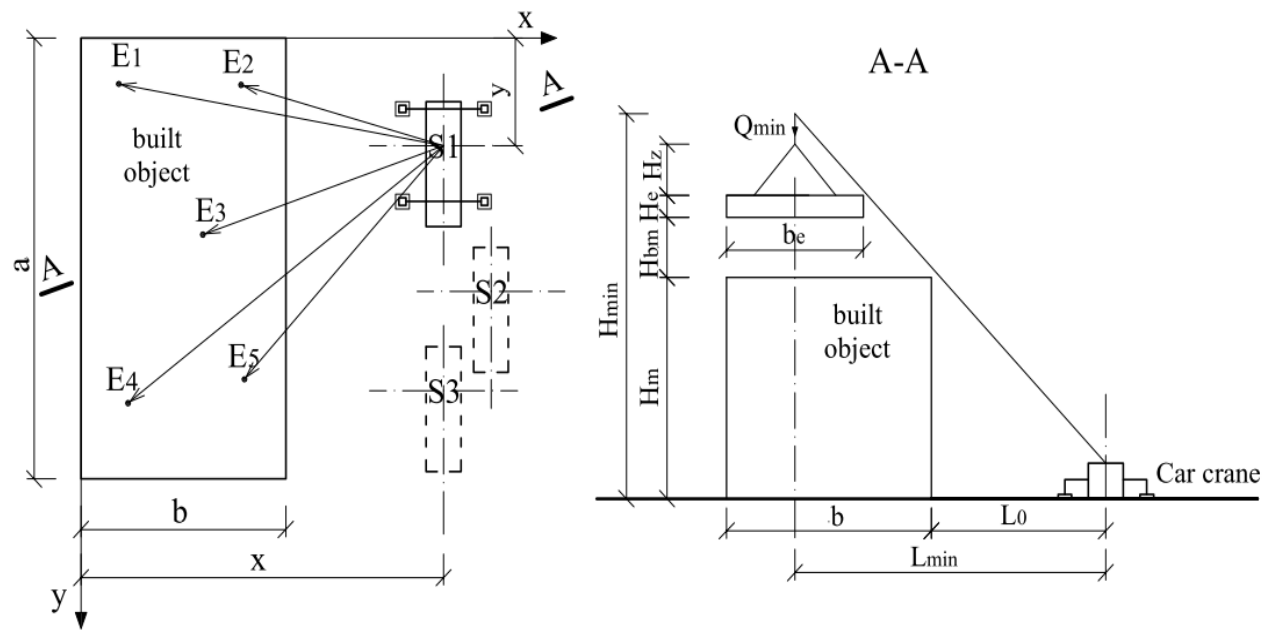

Fig. 2. The analysis of the position of a crane on the selected assembly positions

Of course the organiser of assembly works wants the specified location of the crane to be used for performing the assembly in the largest extent. This will allow limiting of the operations of moving of the crane to different assembly positions, which shortens the operating time of the crane, and thus limits the downtime of the assembly team. What is equally important it simplifies the logistic works connected with the current supply of prefabricates to the construction site for the assembly from the 
specified location of the crane. In many cases, the free positioning of the locations of the crane is limited by the conditions on the construction site. Assuming the last issue as the most common on construction sites, we assume that the problem of the location of the car crane will be solved by selecting an optimal positioning from the determined possible locations for the crane. With reference to every possible location of the crane the conditions and characteristic parameters of the assembly of prefabricates with specified sizes, weights and installation locations will be specified. The assembly situation is illustrated in fig. 2 .

Referring to the assembly situation presented in fig. 2 in the solution of the problem one should specify the necessary parameters $\left\{Q_{\min }, L_{\min }, H_{\min }\right\}$ of the crane for the assembly of elements $\left\{E_{1}\right.$, $\left.E_{2}, \ldots E_{e}\right\}$ from the positions $\left\{S_{1}, S_{2}, \ldots S_{s}\right\}$. For calculations the use of a spreadsheets is proposed, e.g., from Excel. The spreadsheet should be programmed to calculate the necessary parameters $\left\{Q_{\min }, L_{\min }, H_{\min }\right\}$ depending on the crane's situation, which will be identified by variables $\{\mathrm{x}, \mathrm{y}\}$.

\section{THE DECISION-MAKING SITUATION MODEL}

The problem with the positioning of the car crane for the assembly of prefabricates can be formulated differently. This entails various models of the decision-making situations. In the work we limit ourselves to the determination (selection) of one location $S_{\text {opt }}$ from many possible ones, specified by the formula $S=\left\{S_{1}, S_{2}, \ldots S_{s}\right\}$, for which the set of necessary parameters $\left\{Q_{\min }, L_{\min }\right.$, $\left.H_{\min }\right\}$, determined for particular elements $E=\left\{E_{1}, E_{2}, \ldots E_{e}\right\}$ generates the need to employ a crane with the smallest nominal load $Q_{\mathrm{dz} .}$. The nominal load of the crane is treated here as the measure characterising the machine, and not as the parameter connected with the particular assembly situation.

If we assume that for the set $E$ we will define the set of necessary parameters of the crane $\left\{Q_{\min }^{i}, L_{\min }^{i}, H_{\min }^{i}\right\}$ dla $i: e_{i} \in E$, the crane which can perform the assembly work, involving the assembly of all elements of the set $E$, must be characterized by greater loads for the required $L_{\mathrm{min}}$ and $H_{\min }$. A crane with the nominal load $Q_{\mathrm{dz}}\left(S_{k}\right)$ from the position $S_{k}$ should, therefore, meet the conditions for $i: e_{i} \in E$ :

$$
Q_{d z}^{i} \geq Q_{\min }^{i} \quad \text { dla } \quad\left\{L_{\min }^{i}, H_{\min }^{i}\right\}
$$


From the characteristic sizes of car cranes needed to perform the assembly of prefabricates from the distinguished assembly positions $\left\{S_{1}, S_{2}, \ldots S_{s}\right\}$, we determine that the most advantageous position to perform the assembly of prefabricates is $S_{o p t} \in S$ for which:

$$
Q_{d z}=\min \left\{Q_{d z}\left(S_{1}\right), Q_{d z}\left(S_{2}\right), \ldots, Q_{d z}\left(S_{s}\right)\right\}
$$

The presented model of the task is based on the assumption that the set of elements for the assembly from the given position is specified. In many situations, however, there may arise a problem related to the process of determining of the assembly positions of a crane and the scope of assembly - the sets of assembly elements from these locations. This issue will be the subject of other publications.

\section{THE PROPOSED METHOD OF A SOLUTION WITH AN EXAMPLE}

To assist in solving of the presented problem a spreadsheet was developed in Excel. The data from the first performed spreadsheet analysis should specify the characteristics of prefabricates, their positioning in the object, dimensional characteristics of the object and the coordinates of the proposed assembly positions. The solved situation is illustrated by fig. 2 . The spreadsheet was designed so that some characteristics of the assembly situation, such as $L_{0}, b, b_{e}$, were calculated in the spreadsheet automatically based on the analysis of coordinates of the position of the crane and coordinates of the positions of assembly of prefabricated elements.

Sample data are presented in table 1. Based on them the computer program determines the necessary parameters of the assembly machine (tab. 2). The markings of the characteristics set in these tables are consistent with figure 2 .

Table 1. Data for an example

\begin{tabular}{|c|c|c|c|c|c|c|c|c|c|c|c|c|c|}
\hline \multirow{2}{*}{$\begin{array}{l}\text { El. } \\
\text { No. }\end{array}$} & \multirow{2}{*}{ Name of the element } & \multicolumn{2}{|c|}{$\begin{array}{l}\text { Dimensions of } \\
\text { the built object }\end{array}$} & \multicolumn{10}{|c|}{ Characteristics of the assembled elements and suspensions } \\
\hline & & $\mathrm{b}[\mathrm{m}]$ & $\begin{array}{l}\mathrm{H}_{\mathrm{m}} \\
{[\mathrm{m}]}\end{array}$ & $\begin{array}{l}\mathrm{b}_{\mathrm{e}} \\
{[\mathrm{m}]}\end{array}$ & $\begin{array}{c}\mathrm{l}_{\mathrm{e}} \\
{[\mathrm{m}]}\end{array}$ & $\begin{array}{l}\mathrm{H}_{\mathrm{e}} \\
{[\mathrm{m}]}\end{array}$ & $\begin{array}{l}\mathrm{Q}_{\mathrm{e}} \\
{[\mathrm{t}]}\end{array}$ & $\begin{array}{c}\mathrm{x} \\
{[\mathrm{m}]}\end{array}$ & $\begin{array}{c}\mathrm{y} \\
{[\mathrm{m}]}\end{array}$ & $\begin{array}{l}\mathrm{Q}_{\mathrm{z}} \\
{[\mathrm{t}]}\end{array}$ & $\begin{array}{c}\mathrm{Q}_{\text {dod }} \\
{[\mathrm{t}]}\end{array}$ & $\begin{array}{l}\mathrm{H}_{\mathrm{z}} \\
{[\mathrm{m}]}\end{array}$ & $\begin{array}{l}\mathrm{H}_{\mathrm{bm}} \\
{[\mathrm{m}]}\end{array}$ \\
\hline E1 & Can. board. S-240x90x24 & 10,00 & 22,00 & 0,89 & 2,36 & 0,24 & 0,77 & 2,00 & 20,00 & 0,21 & 0,08 & 2,50 & 1,00 \\
\hline E2 & d S-720x90x24 & 10,00 & 22,00 & 1,19 & 7,16 & 0,24 & 2,4 & 1,5 & 16,00 & 0,33 & 0,08 & 2,50 & 1,00 \\
\hline E3 & 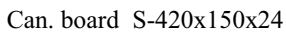 & 10,00 & 22,00 & 1,50 & 4,20 & 0,24 & 2,13 & 6,00 & 12,00 & 0,33 & 0,08 & 2,50 & 1,00 \\
\hline E4 & 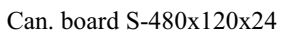 & 10,00 & 22,00 & 1,20 & 4,80 & 0,24 & 1,86 & 6,00 & 6,00 & 0,33 & 0,08 & 2,50 & 1,00 \\
\hline E5 & Sch. gear KB-140/128/30 & 10,00 & 22,00 & 1,28 & 3,22 & 0,30 & 1,74 & 7,50 & 28,50 & 0,05 & 0,00 & 2,00 & 1,00 \\
\hline
\end{tabular}


Table 2. Values $Q_{\min }, L_{\min }, H_{\min }$ for the selected positioning locations of the crane

\begin{tabular}{|c|c|c|c|c|c|c|c|}
\hline \multicolumn{2}{|c|}{$\begin{array}{l}\text { Location of the crane } \\
\text { (coordinates } \mathrm{x}, \mathrm{y} \text { ) }\end{array}$} & \multicolumn{2}{|c|}{$\mathrm{S} 1,(27 ; 8)$} & \multicolumn{2}{|c|}{$\mathrm{S} 2,(15 ; 15)$} & \multicolumn{2}{|c|}{$\mathrm{S} 3,(21 ; 23)$} \\
\hline El. No. & $\mathrm{Q}_{\min }[\mathrm{t}]$ & $\mathrm{L}_{\min }[\mathrm{m}]$ & $\mathrm{H}_{\min }[\mathrm{m}]$ & $\mathrm{L}_{\min }[\mathrm{m}]$ & $\mathrm{H}_{\min }[\mathrm{m}]$ & $\mathrm{L}_{\min }[\mathrm{m}]$ & $\mathrm{H}_{\min }[\mathrm{m}]$ \\
\hline E1 & 1,59 & 27,73 & 29,32 & 13,93 & 43,33 & 19,24 & 37,12 \\
\hline E2 & 4,23 & 26,73 & 31,29 & 13,54 & 58,41 & 20,72 & 34,96 \\
\hline E3 & 3,81 & 21,38 & 26,93 & 9,49 & 35,79 & 18,60 & 26,31 \\
\hline E4 & 3,41 & 21,10 & 27,11 & 12,73 & 28,64 & 22,67 & 25,99 \\
\hline E5 & 2,69 & 28,29 & 25,30 & 15,44 & 26,01 & 14,58 & 26,19 \\
\hline \multicolumn{2}{|c|}{ Required capacity: } & \multicolumn{2}{|c|}{$90 \mathrm{~T}$} & \multicolumn{2}{|c|}{$130 \mathrm{~T}$} & \multicolumn{2}{|c|}{$60 \mathrm{~T}$} \\
\hline
\end{tabular}

To determine the needed nominal load we need the characteristics of assembly cranes. In the presented example the set of cranes of the LIEBHERR type was used. Determining the required nominal load of the crane is supported by the illustration of tabular results (tab.2). Examples of such illustrations are presented in fig. 3, which shows the necessary loads of the crane in the function $L_{\min }$ and $H_{\min }$ for cranes situated in position $S_{2}$ and $S_{3}$. Characteristics of the available cranes, provided by the manufacturers should be compared to the illustration of results from tab. 2 (as in fig.3). This is done by the application of these figures in the uniform scale.
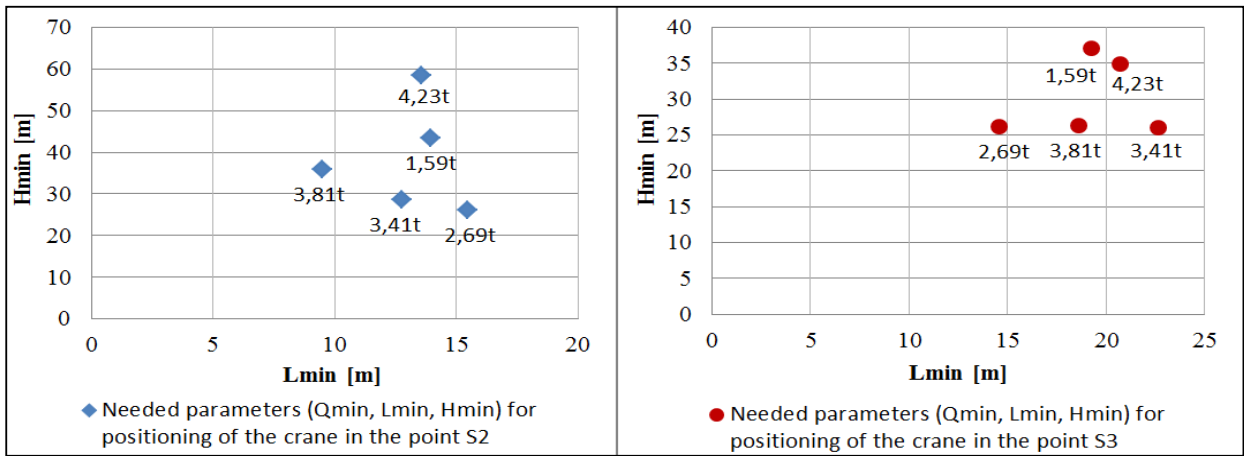

Fig. 3. Graphical presentation of the results - needed parameters of the mobile crane.

It results from the analysis of the most beneficial positioning of the crane is the position $S_{3}$ with coordinates $x=21 \mathrm{~m}, y=23 \mathrm{~m}$ - according to fig. 2 and 3 . The spreadsheet is a relatively flexible analysis tool. By changing the coordinates of the mobile cranes and groups (sets) of prefabricated elements assembled from these positions, we can determine the position of operating locations of cranes for performing certain fragments of the prefabricated structure of the object. 


\section{CONCLUSION}

The selection of assembly machines and locations of their positions on the construction site is extremely important from the onsite topographical point of view, where the prefabricated object is to be assembled. You do not always have the space that you actually need to achieve the effectiveness of assembly works using a crane. The spatial system, types of building forms and construction solutions of the objects shape the needs within those types and operational parameters of assembly machines. Crucial here are the natural environmental manmade factors and conditions of the surroundings, e.g., proximity of other buildings, space, on which the boom has to operate, the height of the lift, characteristics of prefabricated elements, possibilities to merge prefabricates, etc. The implementation of the assembly works thus requires solutions for different technical and organisational problems.

The proposal of the selecting method for the set of assembly machines for the assembly of prefabricated elements based on the selected criteria can be found in [1]. The authors have proposed the use of the multi-criteria method of the comparative analysis AHP (Analytic Hierarchy Process) for the selection of sets of machines for the assembly of prefabricated elements. The method is based on the a priori determined assembly positions of cranes. Its goal is to indicate one of many solutions, where all of them meet the technical conditions of the assembly (can perform the assembly). They are to facilitate the proper recognition of the optimal set of devices, which provide the expected realization and economic effects. However, it is recommended to comprehensively consider the technical, organisational and economic issues of the object assembly. Such studies are conducted in relation to a particular prefabricated object - in the process of developing the assembly project. However, are the solved issues optimised?

The problem of the location of the car crane for performing the assembly work should be solved using the size and characteristics of the machine itself and with the analysis of the assembly characteristics of the object and prefabricates. Also important are the issues of scheduling the assembly works $[2,3]$. The solutions of these issues in all aspects require the further targeted studies, analyses and creative development. 


\section{REFERENCES}

1. D. Biskupska and E. Tomaszewska, „Wybór zestawów maszyn do montażu elementów prefabrykowanych z zastosowaniem metody analizy hierarhicznej (AHP)”, Przegląd Budowlany Nr 1: 63-68, 2012.

2. W. Bożejko, Z. Hejducki, M. Uchroński and M. Wodecki, „System wspomagania harmonogramowania przedsięwzięć budowlanych, Innowacje w zarządzaniu i inżynierii produkcji” (red. R. Knosala). Oficyna Wydawnicza Polskiego Towarzystwa Zarządzania Produkcją: 263-273, Opole, 2012.

3. W. Bożejko, Z. Hejducki, M. Uchroński and M. Wodecki, „Zintegrowany proces transportu i montażu elementów obiektu mostowego, Innowacje w zarządzaniu i inżynierii produkcji” (red. R. Knosala). Oficyna Wydawnicza Polskiego Towarzystwa Zarządzania Produkcją: 273-285, Opole, 2013

4. A. Dyżewski, „Technologia i organizacja budowy”, Arkady, Warszawa, 1989/91.

5. W. Martinek, P. Nowak and P. Wojciechowski, „Technologia robót budowlanych”, Warszawa, Oficyna Wydawnicza Politechniki Warszawskiej, Warszawa, 2010.

Received 22. 06. 2015

Revised 15. 07. 2015

\section{LIST OF FIGURES AND TABLES:}

Fig. 1. Diagram of the assembly situation of the mobile crane with the labelling of characteristic data.

Rys. 1. Schemat sytuacji montażowej dźwigu przejezdnego z oznaczeniami charakterystycznych danych.

Fig. 2. Analysis of the positioning of the crane on the selected assembly positions

Rys. 2. Analiza usytuowania dźwigu na wybranych stanowiskach montażowych

Fig. 3. Graphical presentation of the results - necessary parameters of the mobile crane.

Rys. 3. Graficzne przedstawienie wyników - niezbędnych parametrów żurawia przejezdnego.

Tab. 1. Data for the example

Tab. 1. Dane do przykładu

Tab. 2. $Q_{\min }, L_{\min }, H_{\min }$ values for the selected locations of the crane

Tab. 2. Wartości $Q_{\min }, L_{\min }, H_{\min }$ dla wybranych lokalizacji usytuowania żurawia 


\section{OPTYMALIZACJA USYTUOWANIA ŻURAWIA SAMOCHODOWEGO DO WYKONANIA MONTAŻU KONSTRUKCJI}

Slowa kluczowe: organizacja montażu, montaż prefabrykatów, żuraw samochodowy

\section{STRESZCZENIE:}

Wybór urządzeń montażowych do realizacji prac montażowych na danym placu budowy powinien być poprzedzony ustaleniem niezbędnych parametrów technicznych, jakimi mają się te urządzenia charakteryzować w najniekorzystniejszych możliwych sytuacjach ich pracy. Do parametrów tych należy niezbędny: udźwig - $Q_{\text {min, }}$ wysięg $-L_{\min }$ i wysokość podnoszenia $-H_{\min }$. Wyznaczamy je rozpatrując kilka sytuacji charakterystycznych w planowanym montażu - sytuacji, które generują najniekorzystniejsze sytuacje montażowe. Zidentyfikowanie tych sytuacji nie jest łatwe, szczególnie dla żurawi samochodowych.

Usytuowanie żurawia samochodowego powinno umożliwić wykonanie montażu określonego zbioru prefabrykatów na budowanym obiekcie. Prefabrykaty najczęściej mają różne gabaryty i masy oraz różne miejsca wbudowania.
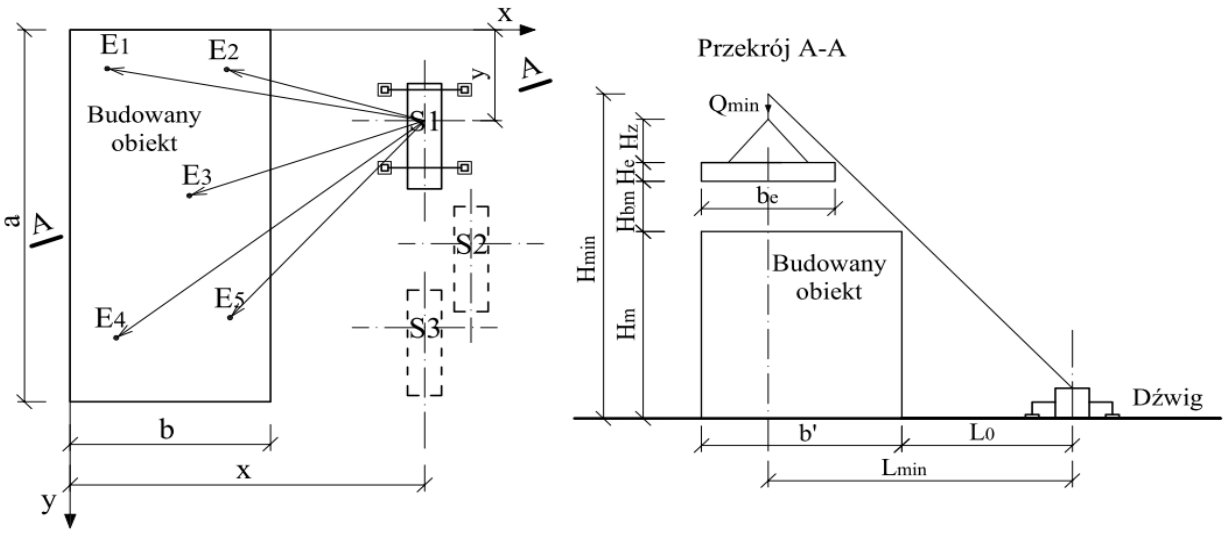

Rys. 1. Analiza usytuowania dźwigu na wybranych stanowiskach montażowych

Oczywiście organizator robót montażowych dąży do tego, aby z określonej lokalizacji żurawia wykonać montaż w największym zakresie. Pozwoli to na ograniczenie operacji przestawiania żurawia na kolejne stanowiska montażowe, co skraca czas pracy żurawia, tym samym ogranicza przestój zespołu montującego, oraz co równie ważne upraszcza prace logistyczne związane $\mathrm{z}$ bieżącym dostarczaniem na budowę prefabrykatów przeznaczonych do montażu z określonej lokalizacji żurawia. W wielu przypadkach swobodne sytuowanie lokalizacji żurawia ograniczają warunki panujące na placu budowy. Przyjmując tę ostatnią kwestię za najczęściej występującą na budowach, zakładamy, że problem usytuowania żurawia samochodowego będziemy rozwiązywali jako wybór jednego optymalnego usytuowania z ustalonych możliwych lokalizacji żurawia.

W pracy ograniczamy się do ustalenia (wyboru) jednego usytuowania $S_{\text {opt }}$ z wielu możliwych, określonych zbiorem $S=\left\{S_{1}, S_{2}, \ldots S_{s}\right\}$, dla którego zbiór niezbędnych parametrów określonych dla poszczególnych elementów $E=\left\{E_{1}, E_{2}, \ldots E_{e}\right\}$ generuje potrzebę zatrudnienia żurawia o najmniejszym udźwigu nominalnym $Q_{\mathrm{dz}}$. 
Udźwig nominalny żurawia traktujemy tu jako wielkość charakteryzującą maszynę, nie zaś jako parametr związany z konkretną sytuacją montażową.

Do rozwiązywania przedstawionego problemu opracowano arkusz kalkulacyjny w programie Excel. Jako dane w analizach wykonywanych arkuszem określono charakterystyki prefabrykatów, ich usytuowanie w obiekcie, charakterystykę wymiarową obiektu oraz współrzędne proponowanych stanowisk montażowych. Rozwiązywaną sytuację obrazuje rys. 1 . Arkusz zaprojektowano tak, aby efektem końcowym były wymagane charakterystyki $\left\{Q_{\text {min, }}\right.$ $\left.L_{\min }, H_{\min }\right\}$ dla każdego montowanego elementu z wybranych lokalizacji żurawia. Przykładowe wyniki w formie wykresów przedstawiono na rys. 2, gdzie pokazano wymagane udźwigi żurawia w funkcji $L_{\min }$ i $H_{\min }$ dla żurawi usytuowanych w wybranych stanowiskach $S_{2}$ i $S_{3}$. Charakterystyki żurawi udostępnianych przez producentów również są opracowane w formule funkcji $L_{\min }$ i $H_{\min }$. Porównanie ich wraz z danymi przedstawionymi na rys. 2 wykonuje się poprzez nałożenie tych rysunków w jednolitej skali. Na podstawie tej analizy określono wymagany udźwig nominalny 130T dla pozycji żurawia $\mathrm{S}_{2}$, oraz $60 \mathrm{~T}$ dla pozycji $\mathrm{S}_{3}$.

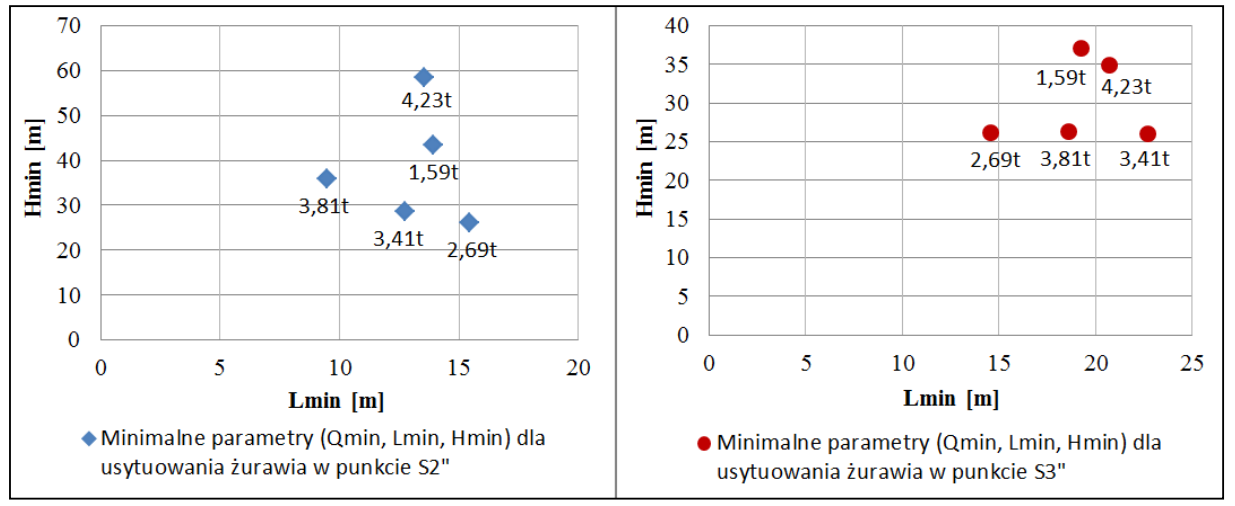

Rys. 2 Graficzne przedstawienie wyników - niezbędnych parametrów żurawia przejezdnego.

Arkusz kalkulacyjny jest stosunkowo elastycznym narzędziem analizy. Poprzez zmiany współrzędnych stanowisk żurawi przejezdnych oraz grup (zbiorów) elementów prefabrykowanych montowanych z tych stanowisk, możemy ustalać lokalizację stanowisk roboczych żurawi do wykonania określonych fragmentów prefabrykowanej konstrukcji obiektu.

Dobór maszyn montażowych i lokalizacji ich stanowisk na placu budowy są niezmiernie istotne z punktu widzenia topografii samego placu budowy, na którym ma być zmontowany obiekt prefabrykowany. Nie zawsze ma się do dyspozycji tyle miejsca, ile faktycznie potrzeba, aby móc osiągnąć dzięki pracy żurawia efektywność prac montażowych. Układ przestrzenny, rodzaje form zabudowy oraz rozwiązania konstrukcyjne obiektów kształtują potrzeby w zakresie typów i parametrów roboczych maszyn montażowych. Realizacja robót montażowych wymaga zatem rozwiązania różnych problemów technicznych i organizacyjnych.

Problem lokalizacji żurawia samochodowego do wykonania pracy montażowej powinien być rozwiązywany z wyborem wielkości i charakterystyki samej maszyny oraz z analizą charakterystyki montażowej obiektu i prefabrykatów. Nie bez znaczenia są też zagadnienia harmonogramowania prac montażowych [1,2]. Rozwiązanie tych zagadnień we wszystkich aspektach wymaga dalszych celowych studiów, analiz i twórczych opracowań. 


\section{BIBLIOGRAFIA}

1. W. Bożejko, Z. Hejducki, M. Uchroński and M. Wodecki, „System wspomagania harmonogramowania przedsięwzięć budowlanych, Innowacje w zarządzaniu i inżynierii produkcji” (red. R. Knosala). Oficyna Wydawnicza Polskiego Towarzystwa Zarządzania Produkcją: 263-273, Opole, 2012.

2. W. Bożejko, Z. Hejducki, M. Uchroński and M. Wodecki, „Zintegrowany proces transportu i montażu elementów obiektu mostowego, Innowacje w zarządzaniu i inżynierii produkcji” (red. R. Knosala). Oficyna Wydawnicza Polskiego Towarzystwa Zarządzania Produkcją: 273-285, Opole, 2013. 